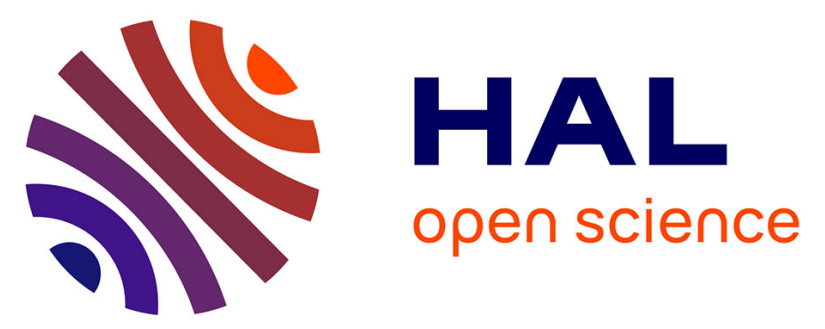

\title{
Global Warming Impact in a Food Distribution System: A Case-Study in an Elementary School in Piaui
}

\author{
Genyvana Carvalho, Ivonalda Almeida Morais, Manoel Eulálio Neto, \\ Raimundo Rodrigues, Francisco Alves, Irenilza De Alencar Nääs, Oduvaldo \\ Vendrametto
}

\section{To cite this version:}

Genyvana Carvalho, Ivonalda Almeida Morais, Manoel Eulálio Neto, Raimundo Rodrigues, Francisco Alves, et al.. Global Warming Impact in a Food Distribution System: A Case-Study in an Elementary School in Piaui. IFIP International Conference on Advances in Production Management Systems (APMS), Sep 2019, Austin, TX, United States. pp.108-115, 10.1007/978-3-030-30000-5_14 . hal02419217

\section{HAL Id: hal-02419217 \\ https://hal.inria.fr/hal-02419217}

Submitted on 19 Dec 2019

HAL is a multi-disciplinary open access archive for the deposit and dissemination of scientific research documents, whether they are published or not. The documents may come from teaching and research institutions in France or abroad, or from public or private research centers.
L'archive ouverte pluridisciplinaire HAL, est destinée au dépôt et à la diffusion de documents scientifiques de niveau recherche, publiés ou non, émanant des établissements d'enseignement et de recherche français ou étrangers, des laboratoires publics ou privés. 


\title{
Global warming impact in a food distribution system: A case-study in an elementary school in Piaui
}

\author{
Genyvana Criscya G. Carvalho ${ }^{[0000-0002-8151-8746]}$ Ivonalda Brito de Almeida Mo-

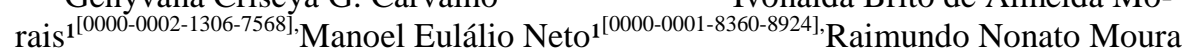

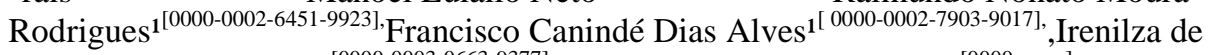 \\ Alencar Nääs ${ }^{1^{[0000-0003-0663-9377], ~}}$ and Oduvaldo Vendrametto ${ }^{10000-x x x x]}$, \\ ${ }^{1}$ Paulista University, São Paulo, Brazil \\ genyvanacarvalho@hotmail.com, ivonaldaa@yahoo.com.br, manoeleula- \\ lo@gmail.com, nonatomoura@gmail.com,canindedias@uol.com.br, irenil- \\ za@gmail.com, oduvaldov@gmail.com
}

\begin{abstract}
The present study aims to evaluate the environmental impact of the food supply system in the State of Piaui, Brazil, through the transport of the provision of school meals from the farm to a public elementary school located in Piracuruca-Piaui. The concepts of 'local food' chains, carbon reduction policies, and global environmental sustainability were applied. The research has an exploratory emphasis and used a survey for analyzing the data. The food used in the school meals was divided into two groups: perishable and non-perishable. The environmental impact study on greenhouse gases emissions focused on perishable food, separating them into two groups: those from family farming and local production, and others from abroad. It was found that it is necessary to improve the logistics of transportation of family farming production, avoiding that each farmer makes the transport of its production individually. Such an initiative might have a significant impact on the reduction of greenhouse gas emissions.
\end{abstract}

Keywords: local food; transportation; logistics; environmental impact.

\section{Introduction}

The development of the so-called 'local-food' chains intends to allow the renewal of the relations between the city and farms [1]. Within the 'local food' global discussion, environmental impacts considered are not restricted to GHG (greenhouse gases) emissions. However, carbon reduction policies may deliver potential trade-offs in overall environmental sustainability until other impacts are entirely considered [2]. The GHG emissions from truck transportation cause a severe burden on climate change since the transport within the supply chains is an essential player in the global carbon dioxide emissions [3]. The road freight segment is a sole contributor to $\mathrm{CO}_{2}$ emissions in large countries such as Brazil [4]. Diesel on-road trucks travel vast distances from the farms to the food distribution centers in the country. The Global Warming Potential (GWP) was developed to permit comparisons of the global warming impacts of different gases. It is a measure of how much energy the emissions of $1 \mathrm{t}$ of gas will absorb over a given period, relative to the emissions of $1 \mathrm{t}$ of $\mathrm{CO}_{2}$ [5].

The current case-study aimed to evaluate the partial environmental impact of a perishable food supply system (familiar farming) in Piaui State, Brazil. 


\section{$2 \quad$ Literature Review}

The 'local food' concept is based on certain boundaries [6]. (1) Geographic distance: calculated in units of distance, usually with a defined maximum distance; (2) Temporal distance: calculated in units of time, e.g. the food can be trucked to the point of consumption in 24 hours or less; and (3) Political and administrative boundaries: based on municipal, regional, or national borders [1].

\section{Family farming}

The expression of family farming has been studied in academic, political, and social scopes. In order to stimulate social participation and encourage local economies, the federal government established proper legislation [7] that establishes the guidelines for the formulation of the National Policy on Family Agriculture. A family farmer entrepreneur is one who practices agricultural activities, and uses the family's workforce in the activities, and have a family' income derived from that economic activity [7].

In relation to school meals, [8] determines that at least $30 \%$ of the value transferred from the National School Feeding Program (PNAE) by the National Education Development Fund (FNDE) to states, municipalities and the Federal District, should be used for the purchase of food products produced by the family farming. Such an initiative is an important public policy for small farmers to assess the market, allowing them to sell the products more efficiently while benefiting schools that can offer the student's food free of pesticides. Farmers who supply their agricultural products to the county elementary schools in Piracuruca live in a small settlement on the road BR $343,10 \mathrm{~km}$ from the municipality's headquarters. Produce fruits and vegetables and sell in their own residence or provide for dealers of the Municipal Public Market. Their average income is around 1 (one) minimum wage. However, family farmers do not have production all year around compatible with the needs of the schools [8] at the county of Piracuruca.

\section{Strategies of school-meal distribution logistic}

School meals in the present county have a warehouse in which the food received from the producers is stored (Fig. 1). The city council then takes responsibility for distributing food from the storage (deposit lunch) to schools. In this distribution process, a schedule prepared by the school nutritionist is considered, which contains all the necessary weekly information, such as the number of products, menu, and other recommendations regarding food preparation. The separation of these foods immediately is made by the demand of each school. The transportation is carried out once a week on the morning shift on each Monday.

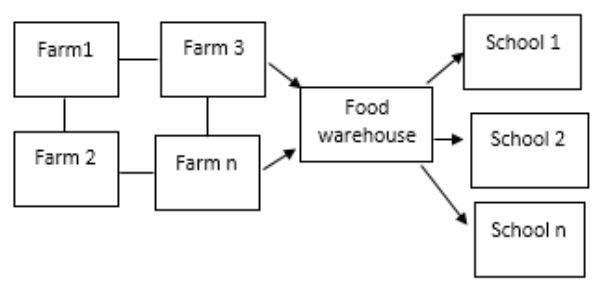


Fig. 1. Logistics flowchart for school meal distribution

The distribution logistics of family farming products is still one of the main restrictions experienced by farmers [9]. School meals in the present county have a warehouse in which the food received from the producers is stored. The county council distributes the food to schools. The vehicle used to perform this transport is a pickup truck. The possible contribution of local sales chains to the reduction of energy consumption has been debated in recent years. Results of comparing the fuel consumption from different modes of distribution of fruits and vegetables in a region of France was discussed by [10].

\section{Methods}

For the investigation of the subject, a survey was carried out in an elementary school with 350 students enrolled in the county of Piracuruca that is in the State of Piauí. According to data of the [11] has income HDI (Human Development Index) is 0.575, and is located in the geographic microregion of the Piaui coast, comprising a territorial area of 2,134 $\mathrm{km}^{2}$, with an estimated population of 27,553 inhabitants and the GDP of the county in relation to agricultural activity is US\$2,398.82, the industry sector is US\$ 3,504.95, and service is equivalent to US\$ 23,461.64.

The economy of the county develops around the Agri-industry with emphasis on the production of cashew nuts, honey production, fish farming, and family farming that is cultivated in small farms along the banks of the Piracuruca dam, which accumulates 250 million cubic meters of water where hundreds of families produce vegetables throughout the year.

\section{Selected boundaries for the analysis}

The research focused on the volume of food transported and the distance from farms to the warehouse distribution center for the elementary school. Transportation was done using pickup truck and motorcycles. Meat, chicken and fruit pulp are transported in a truck adding up to $204 \mathrm{~kg} / \mathrm{month}$, and the bread totaling 1,600 units /month. On motorcycles $290 \mathrm{~kg} /$ month of products, such as tomatoes, onions, peppers, green scents, sweet potatoes, orange, mandioc, pumpkin).

The products were grouped into two categories: perishable (vegetable and fruit) and non-perishable (processed rice, beans, garlic, chocolate, powdered milk, biscuit, sugar, noodles, tomato extract, soybean oil, seasoning, refined salt, 'coloral' (local seasoning), canned corn, flour, and coffee). The cluster of perishable food products represents $60 \%$ of the total food consumed monthly.

The farmers do transportation using pick-up trucks and motorcycles. The cluster of perishable food products represents $60 \%$ of the total food consumed monthly.

\section{Description of the school-meal logistics in Piracuruca, Brazil}

School meals in the studied county of have the following logistics: all suppliers deliver their products in a central (School Lunch Distribution Center), where the school makes the separation, and then all delivery is done by the responsible for this sector. Perishable foods are delivered once a week, and non-perishable foods are delivered biweekly. 
Thus, the food route for school meals in the "Hermínio Conde" elementary school can be described as follows: the fruit pulp is transported from $9.2 \mathrm{~km}$, packed in a refrigerated vehicle. The other perishable foods are delivered to the warehouse, using transport such as a bicycle and a motorcycle, and travel up to $10 \mathrm{~km}$. Non-perishable foods come from long distances. The leftovers from the previous delivery are collected by the delivery vehicle and taken to a reserved area for redistribution. In this way, waste is always avoided. The school manager is advised to check, at the time of receiving the products, the expiration date as well as the aspect of each food, such as color, and consistency. Such special care is aimed at avoiding foods that have expired or that expire before the day they are served to the students.

The survey focused on the amount of food transported and the distance from farms to the school. The perishable foods are vegetables and fruits, and non-perishables are processed rice, beans, and others. Calculations were made, considering the reference values of one month of school meals in a public elementary school. A projection of these values was made for a school year, which, in this case, corresponds to ten months, given the need to subtract the 45 days of school vacations. After the calculations were completed, the total kilograms were converted into tons. Concerning the sample criterion, the present research is limited to non-perishable products produced in the region used in school meals. Fig. 2 indicates the scheme of delimitation in the current study.

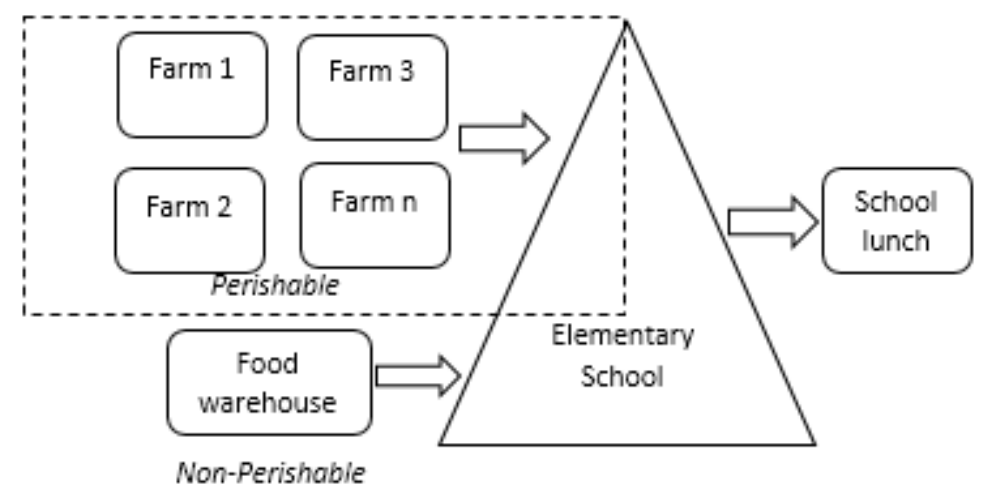

Fig. 2. Scheme of the geographic limits of the study of the environmental impact of the school-meal logistics of perishable food.

\section{Global warming impact assessment}

The information was collected through analysis of tables used for the menu of meals composed of food products of March 2019. The values of the $\mathrm{CO}_{2}$ equivalent $\left(\mathrm{CO}_{2}\right.$ eq) emissions were estimated adopting the 100-yr Global Warming Potential (GWP) values used by the Fourth Assessment Report (AR4) of the IPCC [12] and using the online calculator [13]. The online calculator uses as input the distance traveled and the average fuel consumption, and the result is the amount of $\mathrm{CO}_{2}$-eq/year, referred to the GWP in 100 years [14]. 


\section{$4 \quad$ Result and Discussion}

After analyzing the data, it was observed that the use of local sales chains in school meals brings benefits from the social point of view. The incentive of such a production generates income and boosts the economy of the municipality, besides including small farmers in the local market. Such a benefit goes beyond the social analysis since through the current study it was found that energy consumption and GHG emissions in the environment decreased significantly when the foods travel short distances to their destination, contributing to environmental preservation.

The results of the energy consumption of different modes of fruit and vegetable distribution were presented (Table 1), as suggested by [10], and it was verified that the food produced near the county's headquarters has a lower impact than that produced in another county located $95.4 \mathrm{~km}$ from Piracuruca, as seen in the results of the fruit pulp. These policies to reduce carbon emissions, according to [2] are potential trade-offs in global environmental sustainability. The lower the distance in transport, the less GHG emission.

Table 1. Perishable products analyzed for one year, the quantity ( $\mathrm{t}$ ), the corresponding traveled distance $(\mathrm{km})$ from the farm to the elementary school case-study, and the global warming impact.

\begin{tabular}{lcccc}
\hline Product & $\begin{array}{c}\text { Quantity } \\
(\mathbf{t})\end{array}$ & $\begin{array}{c}\text { Distance } \\
(\mathbf{k m})\end{array}$ & Fuel type & $\begin{array}{c}\text { GWP }\left(\mathbf{C O}_{\mathbf{2}} \text {-eq } \mathbf{~} \mathbf{x} \mathbf{1 0}^{-4} \text { in }\right. \\
\mathbf{1 0 0 y s})\end{array}$ \\
\hline $\begin{array}{l}\text { Fruit pulp } \\
\text { Fresh }\end{array}$ & 0.64 & 7,616 & diesel & 288 \\
bread & 0.08 & 80 & diesel & 30 \\
$\begin{array}{l}\text { Ground } \\
\text { beef }\end{array}$ & 0.44 & 80 & diesel & 30 \\
Broiler & 0.96 & 80 & diesel & 30 \\
breast & & & & \\
Tomato & 0.18 & 800 & gasoline & 50 \\
Onion & 0.18 & 800 & gasoline & 50 \\
Green & 0.06 & 800 & gasoline & 50 \\
pepper & & & & \\
Cilantro & 0.96 & 800 & gasoline & 50 \\
Sweet & 0.16 & 800 & gasoline & 50 \\
potato & & & & \\
Orange & 1.04 & 800 & gasoline & 50 \\
Manioc & 0.16 & 800 & gasoline & 50 \\
Pumpkin & 0.16 & 800 & gasoline & 50 \\
\hline
\end{tabular}

Note: The school year corresponds to 10 consequent months, with 5-days/week

Table 1 shows that, although it is verified that the perishable food is transported in less than 24 hours (one of the characteristics of the 'local food'), it consumes less energy in its transport. The production is made by family farmers, which each produces and delivery a product individually, using their transport (motorcycle). Thus, the sum of GHG emissions in the transport of the products (tomatoes, onions, peppers, green odor, sweet potatoes, orange, cassava, and pumpkin) corresponds to 400 
GWP. While the sum of the GHG emission values of the others shown in Table 1 (fruit pulp, ground meat, cold broiler chest, and bread) corresponds to a lower value (378 GWP; even considering that one of these products, the fruit pulp, traveled a total distance of 7,616 km) and all other products take up only $6,640 \mathrm{~km}$. Such results lead to the conclusion that it is not enough to search for local sales chains, it is necessary to improve the logistics of transport, causing this production to be transported together, avoiding that each farmer transports the agricultural production individually, which will significantly impact emissions from greenhouse gases.

Figure 3 shows the relationship between the GWP and the distance of food distribution, and the fuel used to transport the food-products.

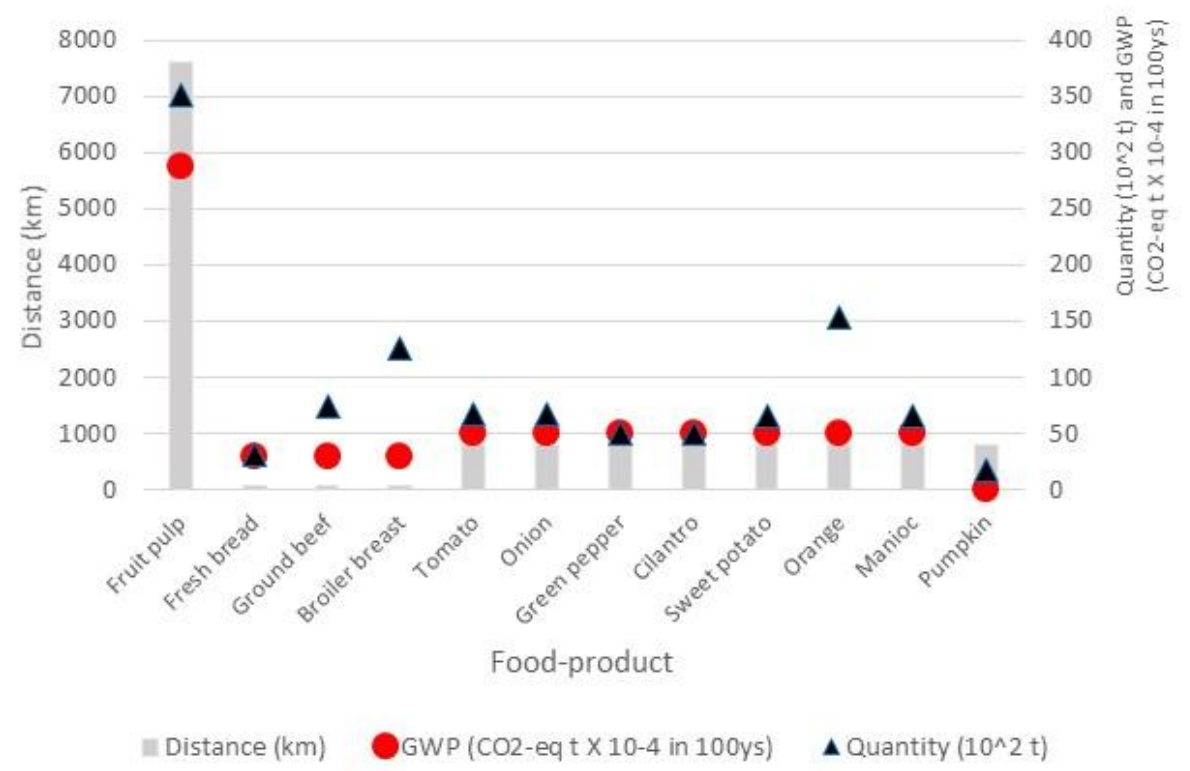

Fig. 3. Results of the GWP based on the amount of fuel used in the transportation of perishable food.

One intrinsic part of a globalized food order has to do with market segmentation and with the corresponding consumer reaction [15]. It is also related to a growing understanding that the properties of food are 'natural' properties and that the heterogeneity of farm environments improves the aspects of the various foods. Therefore, there is a potential for logistical optimization in 'local food' chains. Such chains are newer than long and already established chains, and the logistics experience is being built-up lately. Those local-food chains have room for improvement, which could significantly improve the performance in terms of distribution and reaching their consumers [10].

Based on data analysis, 'local food' is a sustainable way of buying food since it implies social sustainability and it places small farmers in the market and boosts the municipality's economy and incorporates environmental sustainability. Transportation 
in trucks, energy consumption, and GHG emissions are also reduced. However, if the logistics of such transport are not well planned, this energy consumption can increase and threaten the carbon reduction policy in the environment. Regarding those aspects, such a form of acquisition is still the most socially and environmentally sustainable.

\section{$5 \quad$ Final Remarks}

Based on the present data analysis, 'local food' seems a sustainable way of acquiring food since it implies social sustainability since it places small farmers in the market and boosts the municipality's economy and in environmental sustainability. Reduce the transportation of trucks, energy consumption, and GHG emissions are also reduced. However, if the logistics of such transport are not well planned, this energy consumption can increase and threaten the carbon reduction policy in the environment. Such a form of acquisition is still the most socially and environmentally sustainable.

Potential strategies to develop a 'local food' system include promotional programs focused on local consumers, institutional purchasing programs that create direct links between local growers and local institutions, low-interest small loan programs for small or family farmers. Establishing a cost-share program may also help farmers transition to 'local food' production. Other important step includes increased food processing capacity in areas close to the consumption center that would amplify the local and regional market access.

\section{References}

1. DuPuis, M., Goodman, D. Should we go 'home' to eat? Towards a reflexive politics in localism. Journal of Rural Studies 21: 359-371, 2005.

2. Rothwell, A., Ridoutt, B., Page, G., Bellotti, W. Environmental performance of local food: Trade-offs and implications for climate resilience in a developed city. Journal of Cleaner Production 114:420-430, 2016.

3. Dente, S. M. R., Tavasszy, L. Policy-oriented emission factors for road freight transport. Transportation Research Part D 61: 33-41, 2018.

4. Welle, D. What represents the transport by trucks for Brazilian supply chains? 2018. Available at: https://www.cartacapital.com.br/economia/o-que-otransporte-por-caminhoes-representa-para-o-brasil. Accessed March 19, 2019.

5. Lashof, D. A., Ahuja, D. R. Relative contributions of greenhouse gas emissions to global warming. Nature, 344: 529-531, 1990.

6. Smith, A., Mackinnon, J.B. The 100-Mile Diet: A Year of Local Eating. Random House, Toronto, 2007.

7. Brasil. Lei $\mathbf{n}^{\mathbf{0}}$ 11.326. Brasília, DF 25 de julho de 2006. Available at: http://www.planalto.gov.br/ccivil_03/_Ato2004-2006/2006/Lei/L11326.htm. AccessedMarch 19, 2019.

8. Brasil. Lei $\mathbf{n}^{\mathbf{0}}$ 11.947, de 16 de junho de 2009. Available at: https://www2.camara.leg.br/legin/fed/lei/2009/lei-11947-16-junho-2009-588910normaatualizada-pl.html. Accessed March 19, 2019. 
9. De Mendonça, L. C. U., Batista, J. C. P., do Nascimento, A. C., dos Santos Sá, M., \& de Souza Leite, D. T. B. (2017, December). Programa Nacional de Alimentação Escolar: Uma Análise da Importância da Logística de Distribuição. In Congresso de Gestão, Negócios e Tecnologia da InformaçãoCONGENTI (v. 1, n. 1).

10. Mundler, P., Rumpus, L. 2012. The energy efficiency of local food systems: A comparison between different modes of distribution. Food Policy 37: 609-615.

11. IBGE 2016. Piracuruca municipality. Available at: https://www.ibge.gov.br/cidades-e-estados/pi/piracuruca.html. Accessed March 19, 2019.

12. Forster, $P$ et al. Changes in atmospheric constituents and in radiative forcing. In: Climate Change 2007: The Physical Science Basis. Cambridge University Press, United Kingdom and New York, NY, USA. Contribution of Working Group I to the Fourth Assessment Report of the Intergovernmental Panel on Climate Change, 2007.

13. CFC- Carbon Footprint Calculator. Vehicle $\mathrm{CO}_{2}$ Emissions Footprint Calculator. 2018. Available at: https:/www.commercialfleet.org/tools/van/carbonfootprint-calculator. Accessed March 19, 2019.

14. Brander, M. Greenhouse gases, $\mathrm{CO}_{2}, \mathrm{CO}_{2} \mathrm{eq}$, and carbon: What do all these terms mean? Econometrica, 1-3. 2012. Available at:https://ecometrica.com/assets/GHGs-CO2-CO2e-and-Carbon-What-Do-TheseMean-v2.1.pdf. Accessed March 19, 2019.

15. Winter, M. Geographies of food: agro-food geographies - food, nature, farmers and agency. Progress in HumanGeography, 29: 609-617, 2005. 